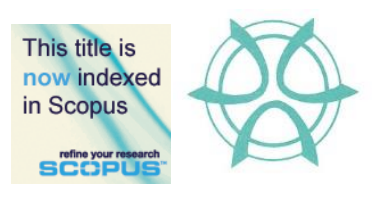

PLANNING MALAYSIA:

Journal of the Malaysian Institute of Planners

VOLUME 16 ISSUE 1 (2018), Page 231 - 238

\title{
ASSESSMENT OF POTENTIAL LOCATIONS FOR BONUS ZONING IN BANDUNG
}

Tika S. D. Hasan ${ }^{1} \&$ Denny Zulkaidi ${ }^{2}$

\author{
${ }^{1,2}$ School of Architecture, Planning, and Policy Development \\ INSTITUT TEKNOLOGI BANDUNG
}

\begin{abstract}
Despite being a common practice in other countries, bonus zoning is still relatively new in Indonesia. Bonus zoning is a zoning regulation tool that allows developers to increase density in exchange for the improvement or provision of public facilities. Bandung, in particular, has already designated areas for bonus zoning within its Local By-law No.10/2015 concerning Detailed Spatial Plan and Zoning Regulation. Its detailed mechanism however is not yet implemented. This research seeks to investigate a) the rationale behind the application of bonus zoning in Bandung; b) the carrying capacity of the areas where bonus zoning could be applied; c) the type of public space to be provided as development compensation; and d) the calculation for compensation. Content analysis was used to review literature and legal documents regarding planning and development in Bandung. This research expects to find which areas are suitable for implementing bonus zoning and come up with its compensation as the basis for sustainable planning in Bandung that not only benefits the developers but also the public as a whole.
\end{abstract}

Keyword: zoning regulation, bonus zoning, public space 
Tika S. D. Hasan \& Denny Zulkaidi

Assessment of Potential Locations for Bonus Zoning in Bandung

\section{INTRODUCTION}

Bonus zoning, or in some literature referred to as incentive zoning, is a measure of development and improvement provided to the developer in return for the provision of public facilities such as arcades, plazas, pedestrian ways, loading and unloading space off the street to avoid congestion in accordance with applicable regulations (Costonis, 1972; Homsy, Abrams, \& Monastra, 2015; Johnston, Schwartz, Wandesforde-Smith, \& Caplan, 1989; Kiefer, 2001; Seyfried, 2007). The practice of bonus zoning has been formally exercised in New York, USA since 1961 when public plazas were built by developers in exchange for supplementary Floor Area Ratio (FAR) for buildings in high-rise areas (Homsy et al., 2015; Smithsimon, 2008).

The City of Chicago makes FAR bonuses available through a single voluntary payment into a Neighbourhood Opportunity Bonus system (City of Chicago, 2017). Previous provisions in the zoning code were regulated by a 2004 regulation that identified a variety of on-site amenities, such as building setbacks, winter gardens, green roofs, and other design features. In 2016, the mayor introduced the following simplified equation for determining the bonus payment system:

Cost of 1 square foot of floor area $=80 \% x$ median cost of land per buildable square foot

As example, when a developer wants to build an additional 5,000 square feet beyond what is allowed under the prevailing zoning regulation in an area where the median price is $\$ 35$ per square foot, the bonus contribution equation for neighbourhood reinvestment would be 5,000 square feet multiplied by $80 \%$ of $\$ 35$ (which is $\$ 28$ ).

5,000 sqft $x 80 \%(\$ 35)=\$ 140,000$

A recent study by the Bandung City Spatial Planning and Human Settlements Office (2016) reported that Jakarta is the first city in Indonesia that has implemented bonus zoning by offering increased FAR from the initial 7 to 13 to a private developer that proposed a new high-rise building. As compensation, the developer provided around IDR 500 billion (approximately USD36 million) for infrastructure investments, which the Jakarta government allocated for the Semanggi Flyover Project as an effort to tackle traffic congestion. The project commenced in April 2016 and was completed in July 2017. The bonus calculation applied in Jakarta is based on Provincial Regulation of DKI Jakarta No.210/2016 as follows: 
PLANNING MALAYSIA

Journal of the Malaysia Institute of Planners (2018)

$$
\begin{aligned}
& C=I \times \frac{A}{F A R_{\text {base }}} \times \text { taxable value of land } \\
& \text { Where; } \quad \mathrm{C}=\text { Compensation value (IDR) }
\end{aligned}
$$

I = Index (as set forth in DKI Jakarta Governor Regulation No. 251/2015 based on the location of the areas where exceeding FAR are allowed with index ranges from 0.6, 0.8, $1.0,1.2,1.4$, to 1.8$)$

$\mathrm{A}=$ Additional floor area $\left(\mathrm{m}^{2}\right)$

$\mathrm{FAR}_{\text {base }}=$ Allowed FAR in Zoning Regulation

Taxable value of land $=$ Sale value on tax object/NJOP (IDR)

As bonus zoning is still uncommon in Indonesia, its implementation requires caution so it will not give the impression of business as usual where developers can build as much as they desire as long as they can afford the compensation value. The carrying capacity of aspects such as water, land, and road level of service must be carefully taken into account before allowing development beyond what is permitted. When applied correctly, bonus zoning can provide local governments with an additional source of funding to boost development, while maintaining the liveability of its area. Bandung urgently needs a well-defined mechanism and procedure of bonus zoning in order to control the overwhelming demand for developments.

\section{BONUS ZONING: BANDUNG CONTEXT}

Bonus zoning is one of the zoning regulation alternatives in Bandung that are accommodated within Local By-law No. 10/2015 on Detailed Spatial Plan and Zoning Regulation in addition to other regulatory techniques such as transfer of development rights (TDR), growth control, and overlay zoning concerning safe flight paths, northern Bandung, and heritage districts. Article 310 directs its application on City Centres (Pusat Pelayanan Kota/PPK), Sub-City Centres (Subpusat Pelayanan Kota/SPK), and City Strategic Areas based on economic interests, integrated areas based on the transit-oriented development (TOD) concept, public service centres with functions comprising traditional buildings and other functions, as well as the construction of public housing/flats for lowincome communities by or in cooperation with private parties. 
Tika S. D. Hasan \& Denny Zulkaidi

Assessment of Potential Locations for Bonus Zoning in Bandung

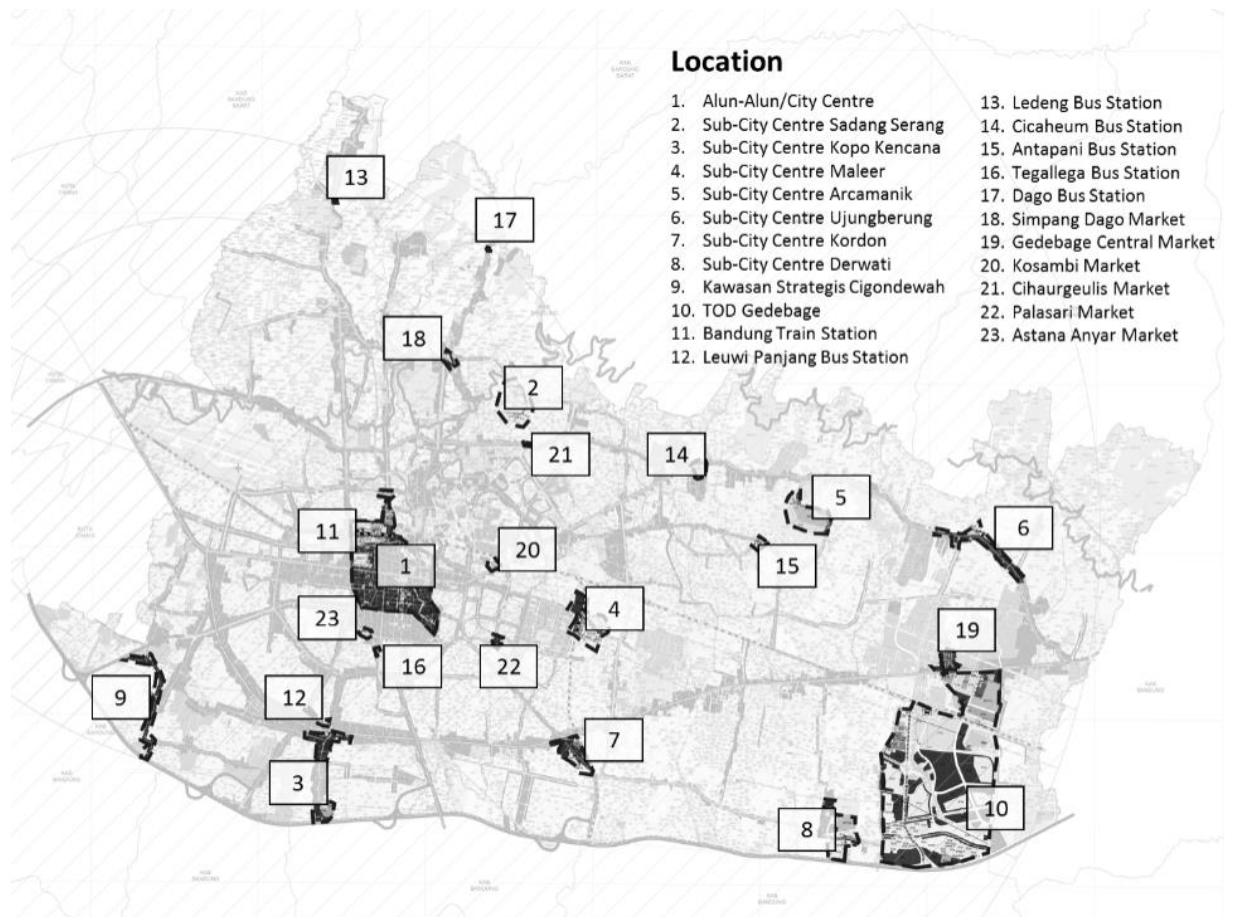

Figure 1: Bonus zoning designated area based on Bandung Local By-law No.10/2015 (Peraturan Daerah Kota Bandung No. 10 Tahun 2015)

Source: Adapted from Bandung Zoning Map within Local By-Law, 2015

This study consists of three sets of analysis. First, determining the implementation of bonus zoning in Bandung was carried out by further examining the designated areas in Local By-law No.10/2015 based on a) the carrying capacity that direct developments to the eastern part of the city; b) the main infrastructure such as road network and road class; c) development policies; d) designated areas for safe flight paths; and e) the possible impact of development such as traffic generation, air and noise pollution, and waste. Table 1 shows the scoring description, while Table 2 presents the scoring result based on these criteria. 
PLANNING MALAYSIA

Journal of the Malaysia Institute of Planners (2018)

Table 1: Score description

\begin{tabular}{|c|c|c|c|}
\hline & 0,5 & 1,0 & 1,5 \\
\hline Carrying Capacity & $\begin{array}{l}\text { High density } \\
\text { location }\end{array}$ & $\begin{array}{l}\text { Medium density } \\
\text { location }\end{array}$ & $\begin{array}{l}\text { Low density } \\
\text { location }\end{array}$ \\
\hline Road Class & Local road & Collector road & Arterial road \\
\hline Development Policy & $\begin{array}{l}\text { Northern, Central, } \\
\text { and Western } \\
\text { Bandung }\end{array}$ & Southern Bandung & Eastern Bandung \\
\hline Safe Flight Path & $\begin{array}{l}\text { Within Safe Flight } \\
\text { Path }\end{array}$ & $\begin{array}{l}\text { Near Safe Flight } \\
\text { Path }\end{array}$ & $\begin{array}{l}\text { Outside } \\
\text { Flight Path }\end{array}$ \\
\hline $\begin{array}{l}\text { Development } \\
\text { Impact }\end{array}$ & Negative & $\begin{array}{l}\text { Neutral, under } \\
\text { acceptable level of } \\
\text { impacts }\end{array}$ & Positive \\
\hline
\end{tabular}

The distribution of locations can be seen in Figure 2 where the lightest shade indicates the highest priority; semi-dark indicates the medium priority; and the darkest shade indicates the lowest priority for additional development intensity - meaning that the dark areas are already high density areas.

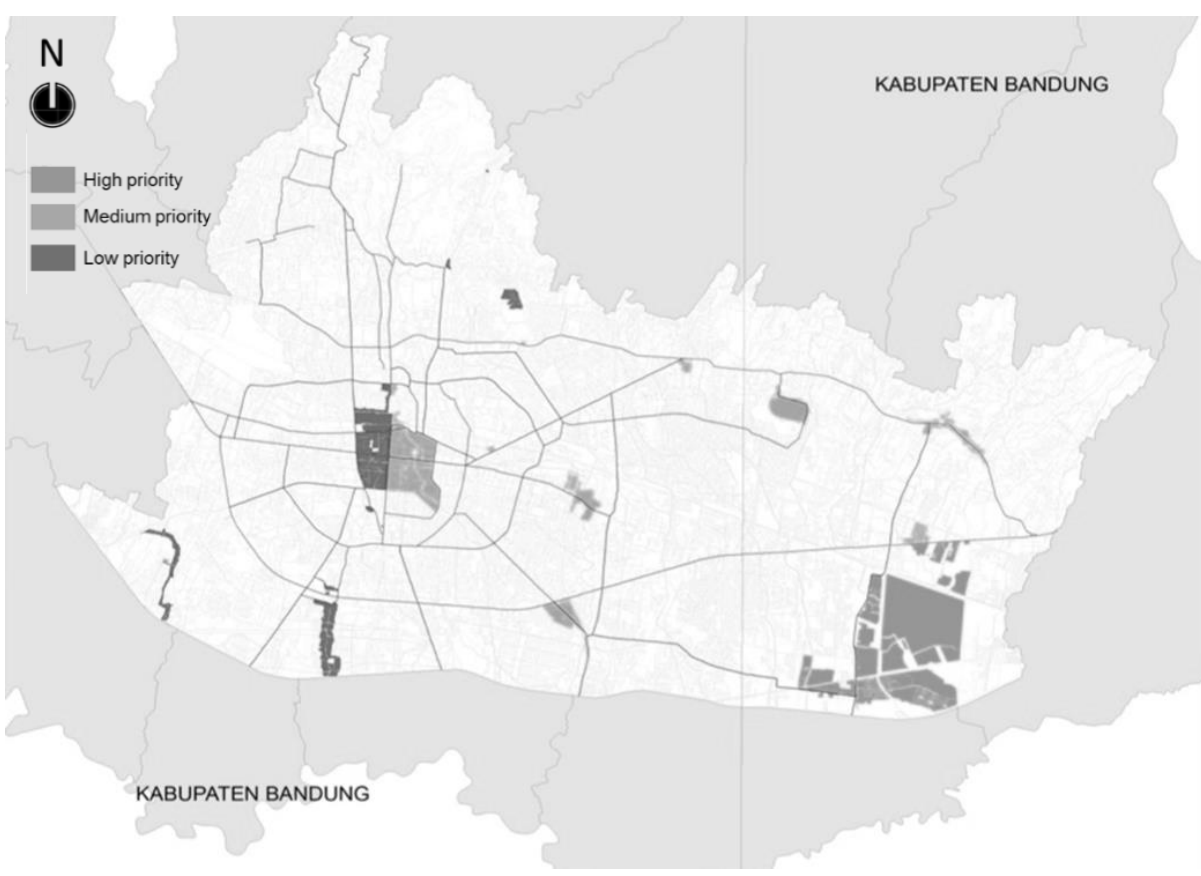

Figure 2: Bonus zoning priority level Source: Adapted from Bandung Zoning Map, 2017 
Tika S. D. Hasan \& Denny Zulkaidi

Assessment of Potential Locations for Bonus Zoning in Bandung

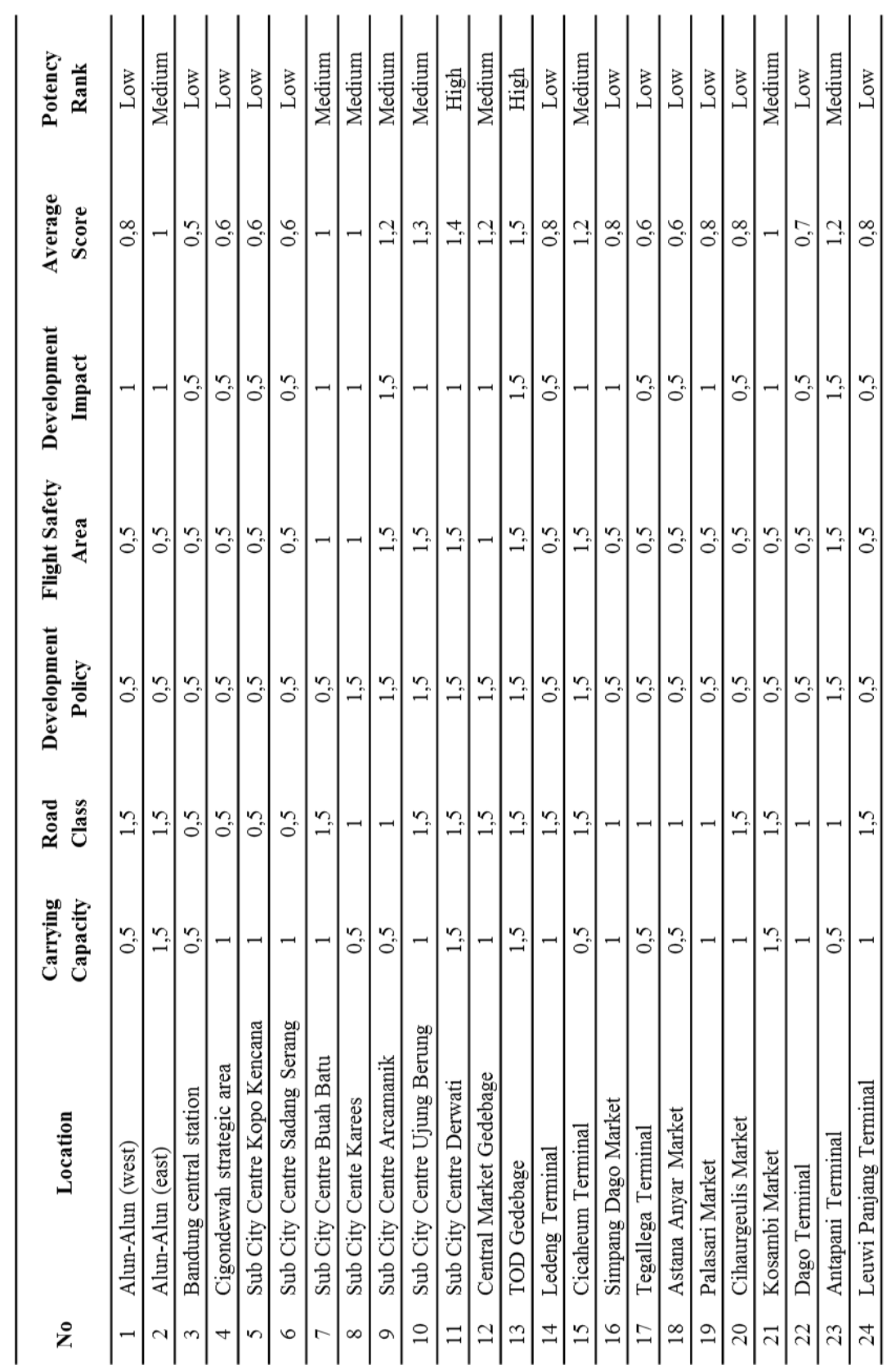

Table 2: Bonus zoning priority level location

Remarks

Potency Risk Low $\quad=0.5-0.8$

Potency Risk Medium $=0.9-1,2$

Potency Risk High $\quad=1.3-1.6$ 
PLANNING MALAYSIA

Journal of the Malaysia Institute of Planners (2018)

The second part of the analysis established the typology of public space that can be distributed into on-site or off-site improvements, which will be ranked, based on the highest demand, for example parking spaces, parks, the improvement and/or widening of pedestrian pathways, and the provision of bike lanes. The final part was to formulate the FAR that can be given as bonus in Bandung.

As opposed to the method being applied in Jakarta where developers propose certain additional FAR in advance and then the local government calculates the compensation that must be paid, this research argues that the calculation method should be reversed. Instead, the developer must provide public amenities beforehand and then the local government would calculate the bonus FAR based on the type of public space the developer provided. This reversed method is important in order to control developers building as much as they desire just because they can afford the compensation.

At this stage of the study, the indication of public space demand in Bandung points towards the provision of parking spaces and green spaces. In addition, to create more walkable neighbourhoods in Bandung, the quality of pedestrian pathways must also be improved. The bonus FAR was tested using the following formula:

Bonus FAR $=\frac{\text { public space provided }(\text { sqm })}{\text { development lot } \text { area }(\text { sqm })} \times \mathrm{I}_{\mathrm{F}} \mathrm{FAR}_{\text {base }}$

The range of index (I) can be determined based on the type of public space that has been provided by the developer. The range between $0<\mathrm{I}<1$ is prioritised with the following preference Table 3):

Table 3: Index range for public space provision

\begin{tabular}{ll}
\hline & Index \\
\hline Public plaza and pocket park & 1 \\
Through-block connection indoor & 0.5 \\
Through-block connection outdoor & 0.7 \\
Parking space & 1 \\
Sidewalk widening & 1 \\
Arcades & 0.3 \\
\hline
\end{tabular}

Suppose, a developer built additional parking space of $10,000 \mathrm{sqm}$ in a development area of 15,000 sqm within a site with a FAR base $_{\text {of }}$ 5. Based on the formula, the developer shall receive a bonus FAR of 3 .

In addition to evaluating the proposed development sites to obtain additional density, the location of the compensated public space is also important to be taken into account. The compensated public space must meet the following conditions, a) meet the carrying capacity of the area, as an already dense location 
Tika S. D. Hasan \& Denny Zulkaidi

Assessment of Potential Locations for Bonus Zoning in Bandung

would not be able to accommodate more activities caused by additional floor area; b) not located within a heritage conservation area/building; c) consider the existing availability and capacity of public infrastructure and utilities; and d) consider the standards for public facilities and infrastructure in demand.

\section{CONCLUSION}

The current stage of the study indicates that Transit Oriented Development (TOD) Gedebage and the Sub City-Centre of Derwati are the top two potential areas to be awarded bonus zoning in return for the provision of public space. However, the result would be different when variables are added, such as the taxable value of land. Changing the scores and indexes would change the result as well. Thus, additional simulations should be considered before a decision is made.

\section{ACKNOWLEDGEMENT}

The researchers would like to acknowledge Ministry of Research Technology and Higher Education of Republic Indonesia for their funding under Higher Education Research of Excellence scheme that made this research possible.

\section{REFERENCES}

Bandung City Spatial Planning and Human Settlements Office (2016). Penyusunan kajian dan raperwal tentang teknik pengaturan zonasi bonus zoning. Dinas tata ruang dan cipta karya Kota Bandung

City of Chicago (2017). Neighborhood opportunity bonus: Leveraging downtown zoning to foster neighborhood development and central area growth. Retrieved from https://www.cityofchicago.org /city/en/depts/dcd/supp_info/realigning-zoningwith-neighborhood-growth.html

Costonis, J. J. (1972). The Chicago Plan: Incentive zoning and the preservation of urban landmarks. Harvard Law Review, 85, 574-634.

Homsy, G. C., Abrams, G., \& Monastra, V. (2015). Incentive zoning: Understanding a market-based planning tool. Public Administration Faculty Scholarship, 5. Retrieved from https://orb.binghamton.edu/public_admin_fac/5

Johnston, R. A., Schwartz, S. I., Wandesforde-Smith, G. A., \& Caplan, M. (1989). Selling zoning: Do density bonus incentives for moderate-cost housing work. Journal of Urban and Contemporary Law, 36, 45-61.

Kiefer, M. J. (2001). Privatizing creation of the public realm: the fruits of New York City's incentive zoning regulation. Environmental Affairs Law Review, 28(4), 637.

Local By-law No.10/2015 (Bandung).

Provincial Regulation of DKI Jakarta No. 210/2016 (Jakarta).

Seyfried, W. R. (2007). Measuring the feasibility of a zoning bonus. Journal of the American Planning Association, 57(3), 348-356.

Smithsimon, G. (2008). Dispersing the crowd: Bonus plazas and the creation of public space. Urban Affairs Review, 43(3), 325-351 